\title{
Systemic Arterial Hypertension in people living with HIV/AIDS: integrative review
}

\author{
Hipertensão arterial sistêmica em pessoas vivendo com HIV/aids: revisão integrativa
}

Hipertensión arterial sistémica en personas que viven con VIH/Sida: revisión integradora

\section{Maria Amanda Correia Lima', Gilmara Holanda da Cunha',"I, Marli Teresinha Gimeniz Galvão", Ryvanne Paulino Rocha', Kátia Barbosa Franco', Marina Soares Monteiro Fontenele' \\ ' Universidade Federal do Ceará, Department of Nursing, \\ Health Care Research Group on HIVIAIDS and Chronic Conditions. Fortaleza, Ceará, Brazil. \\ "Universidade Federal do Ceará, Department of Nursing, \\ Research Group and Center of Studies on HIVIAIDS and Associated Diseases. Fortaleza, Ceará, Brazil.}

How to cite this article:

Lima, MAC, Cunha GH, Galvão MTG, Rocha RP, Franco KB, Fontenele MSM. Systemic Arterial

Hypertension in people living with HIV/AIDS: integrative review. Rev Bras Enferm [Internet]. 2017;70(6):1309-17.

DOI: http://dx.doi.org/10.1590/0034-7167-2016-0416

Submission: 12-01-2016

Approval: 01-04-2017

\begin{abstract}
Objective: To analyze scientific productions about the relationship between HIV and Systemic Arterial Hypertension (SAH) in people living with HIV/AIDS (PLWHA). Method: Integrative literature review in six databases, held in March 2016. "AIDS" and "hypertension" were the keywords used in Portuguese, English and Spanish languages. We found 248 articles and selected 17. The categories formulated were "prevalence of SAH in PLWHA," "risk factors for SAH in PLWHA" and "adverse events of antiretroviral therapy (ART) that contribute to HAS." Results: There is no consensus whether HIV and ART influence the SAH development, but there are several risk factors for SAH among PLWHA. It was observed that protease inhibitors medicines influence SAH the most. Conclusion: Guidelines for SAH prevention must be performed in all individuals, however, in PLWHA, they must focus on characteristic risk factors of this population.
\end{abstract}

Descriptors: Acquired Immunodeficiency Syndrome; HIV; Hypertension; Nursing; Health Promotion.

\section{RESUMO}

Objetivo: Analisar as produções científicas sobre a relação entre o HIV e Hipertensão Arterial Sistêmica (HAS) em Pessoas Vivendo com HIV/aids (PVHA). Método: Revisão integrativa da literatura em seis bases de dados, realizada no mês de março de 2016. Utilizaram-se os descritores "aids" e "hipertensão", nos idiomas português, inglês e espanhol. Foram encontrados 248 artigos e selecionados 17. As categorias formuladas foram "prevalência de HAS em PVHA", "fatores de risco para HAS em PVHA" e "eventos adversos da terapia antirretroviral (TARV) que contribuem para HAS". Resultados: Não há consenso se o HIV e TARV influenciam no desenvolvimento da HAS, mas existem diversos fatores de risco para HAS entre PVHA. Constata-se que os fármacos inibidores de protease são os que mais influenciam na HAS. Conclusão: As orientações para prevenção da HAS devem ser realizadas em todos os indivíduos, porém, nas PVHAs, devem focar nos fatores de risco característicos dessa população.

Descritores: Síndrome da Imunodeficiência Adquirida; HIV; Hipertensão; Enfermagem; Promoção da Saúde.

\section{RESUMEN}

Objetivo: Analizar la producción científica sobre la relación entre el VIH y la Hipertensión Arterial (HTA) en Personas que Viven con el VIH/sida (PVVS). Método: Revisión integradora de la literatura en seis bases de datos, realizada en marzo de 2016. Se utilizaron los descriptores "sida" y "hipertensión" en portugués, inglés y español. Se encontraron 248 artículos, entre los cuales se seleccionaron 17. Las categorías formuladas fueron "prevalencia de la HTA en PVVS", "factores de riesgo de HTA en PVVS" y "eventos adversos de la terapia antirretroviral (TAR) que contribuyen con la HTA". Resultados: No hay consenso si el VIH y la TAR 
influyen en el desarrollo de la HTA, pero hay varios factores de riesgo de HTA entre PVVS. Se constató que los fármacos inhibidores de la proteasa son los que más influencian en la HTA. Conclusión: Las directrices para la prevención de la HTA deben ser puestas en práctica en todos los individuos. Sin embargo, en PVVS, deberían centrarse en factores de riesgo propios de esta población.

Descriptores: Síndrome de Inmunodeficiencia Adquirida; VIH; Hipertensión; Enfermería; Promoción de la Salud.

\section{CORRESPONDING AUTHOR}

\section{INTRODUCTION}

The global AIDS epidemic started in 1981, in the United States $^{(2)}$. Currently, around 34 million people live with HIV/ AIDS (PLWHA), representing a growing pandemic, which is a challenge to many social sectors regarding control measures of vulnerabilities involved in individual and contextual aspects of exposure to the virus ${ }^{(3)}$.

In Brazil, over the decades, HIV infection has gone through changes in its epidemiological profile, which changed the disease natural history. This is mainly due to the introduction of antiretroviral therapy (ART), initiated in the country in 1996. As a result, there was a reduction in mortality and improvement of quality of life of people treating HIV/AIDS(1). The ART initiation, along with prevention and control actions of HIV infection, has been generating changes in the epidemic characteristics. The natural history of the disease changed, it no longer leads to a fast lethal end with standardized attributes, it has become a controllable disease with chronic characteristics and a prolonged evolution ${ }^{(4)}$.

Since PLWHA have a higher survival rate, there is currently a concern with other chronic conditions, one being the systemic arterial hypertension ( $\mathrm{SAH})$, which is also a public health problem, due to the economic impact on the social and health systems, reflecting on the quality of life and life expectancy of individuals. Prevention of irreversible changes in the body requires its continued control, in addition to individual and collective actions ${ }^{(5)}$.

SAH is a multifactorial clinical condition, characterized by high and sustained arterial pressure levels. It is a condition hard to control and among its main risk factors, the following can be highlighted: age, sex, ethnicity, overweight, obesity, hypersodic diet, alcohol abuse, sedentary lifestyle, unfavorable socioeconomic factors, genetic influence, and other cardiovascular risk factors presented connected to one another ${ }^{(6)}$.

Modifiable factors related to lifestyle have often been associated with SAH and, although they have been studied, percentages of knowledge, treatment and control of the disease are still low, both in developed countries as in developing countries. To control SAH, individuals must have knowledge about the disease, since the lack of it stands out as a barrier in the search for orientation for the proper management of the disease $\mathrm{e}^{(7)}$.

This study is justified by the information gap about etiology and development of SAH on PLWHA and the influence of ART, the HIV itself and the risk factors for SAH appearance in these individuals. Therefore, we notice the importance of a bigger understanding about the relationship between HIV and SAH in professional practice, so measures can be taken, minimizing chances of PLWHA to develop SAH. Hence, the objective of this study was to analyze scientific productions about the relationship between HIV/AIDS and SAH.

\section{METHOD}

This integrative review of the literature was prepared in six steps: 1. Elaboration of the guiding question; 2. Research the literature; 3. Data collection; 4. Critical analysis of the studies; 5 . Discussion of results; 6 . Presentation of the integrative review $^{(8)}$. The guiding question was: What is the relationship between HIV/AIDS and SAH?

The articles were selected in six databases: Medical Literature Analysis and Retrieval System Online (MEDLINE), Cumulative Index to Nursing and Allied Health Literature (CINAHL); Índice Bibliográfico Español de Ciencias de la Salud (IBECS); Latin American and Caribbean Literature in Health Sciences (LILACS); Scientific Electronic Library Online (SciELO) and SCOPUS. The survey of articles was carried out in March 2016, using AIDS and Hypertension as descriptors, from the Health Sciences Descriptors (DeCS) of the Virtual Health Library and the Medical Subject Headings (MeSH) of the National Library of Medicine, in Portuguese, English and Spanish languages.

Inclusion criteria were: complete articles available electronically, in Portuguese, English or Spanish languages, involving the topic about HIV/AIDS and SAH, regardless of the year of publication. Exclusion criteria were: letters to editors and repeated articles. Evidence levels were determined as it follows: I. Evidence originating from systematic review or meta-analysis of controlled randomized clinical trials or from clinical guidelines based on systematic reviews of controlled randomized clinical trials; II: Evidence derived from at least one controlled randomized clinical trials; III: Evidence obtained from clinical trials without randomization; IV: Evidence from cohort and case-control studies; $\mathrm{V}$ : Evidence originating from systematic review of descriptive and qualitative studies; VI: Evidence derived from a descriptive or qualitative study; VII: Evidence from opinion of authorities or reports of committees of specialists ${ }^{(9)}$.

Figure 1 shows the quantity of articles selected from the databases. Articles that did not answer the guiding question of the study or were repeated have been excluded.

The 17 articles selected were analyzed through an organized approach to consider accuracy and characteristics of each study, observing methodological development, intervention or care proposed, results, conclusion and evidence level. The studies were gathered into three categories, considering their characteristics: Prevalence of SAH in PLWHA; Risk factors for SAH in PLWHA; and Adverse events of ART that contribute to $\mathrm{SAH}$. The findings were discussed based on scientific literature. 


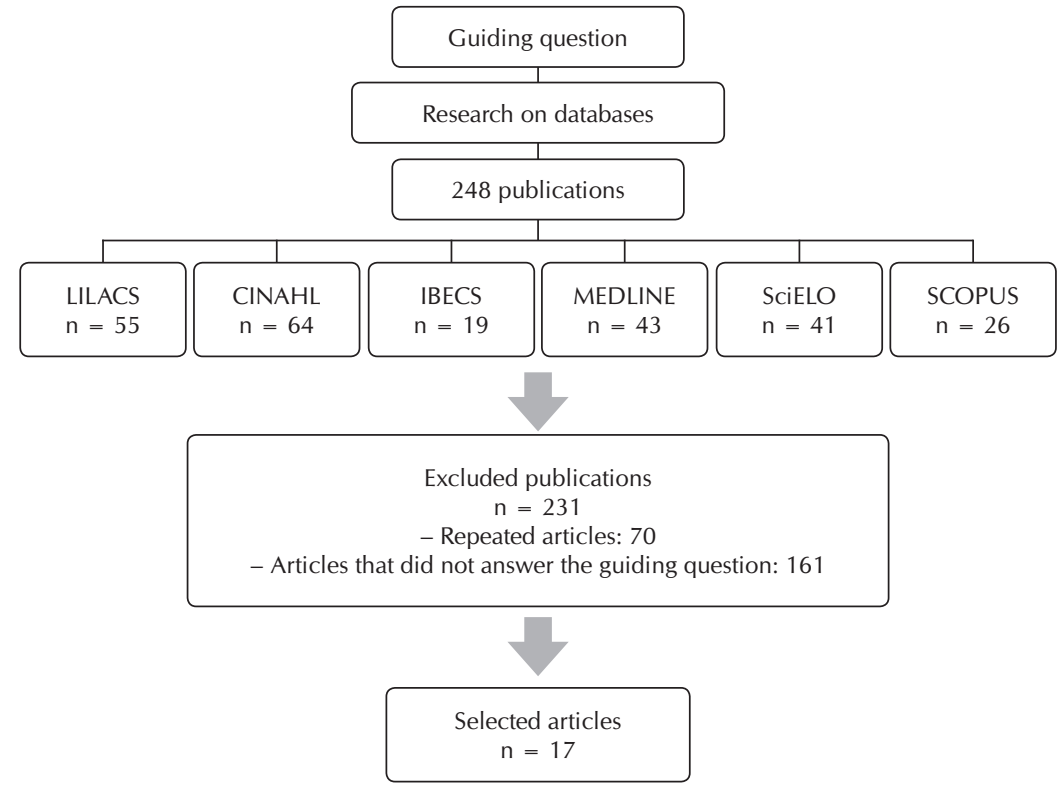

Figure 1 - Distribution of articles found and selected

Regarding ethical aspects, texts and copyrights of the articles were respected, thus, no changes were performed on the content found to favor the study proposed by the authors.

\section{RESULTS}

The characterization of the 17 articles showed the year of publication varied between 2001 and 2016, with six articles published in Brazil(10-15), five in the United States ${ }^{(16-20)}$, four in European countries ${ }^{(21-24)}$, one article in Cameroon ${ }^{(25)}$ and one in Chile $^{(26)}$. Regarding the evidence levels, the following distribution was observed: four on level IV $(10,16,20,23)$; three on level $\mathrm{V}^{(21-22,24)}$; and ten on level $\mathrm{VI}^{(11-19,25-26)}$.
Considering the three categories of the study - Prevalence of SAH in PLWHA; Risk factors for SAH in PLWHA; and Adverse events of ART that contribute to SAH. - , we found that most articles belonged to the first category mentioned. We observed the percentage of PLWHA that have SAH in diverse groups of individuals and in different contexts, such as age, race and using ART or not.

Prevalence of SAH in PLWHA considering the general population is something still under discussion and there is no consensus, which provokes new studies. Something similar happens to PLWHA using ART and, thus, there is the need for more deepening about the subject, since there is no defined position whether ART stimulates development of SAH or not. Chart 1 shows information regarding prevalence of $\mathrm{SAH}$ in PLWHA, emphasizing in which groups of people with HIV/AIDS or situations the $\mathrm{SAH}$ is more frequent.

In the risk factors category for $\mathrm{SAH}$ in PLWHA, we observed there is no consensus whether HIV influences, in fact, the emergence of SAH or it emerges due to causes unrelated to HIV, resulting from time and individual predisposing factors, such as old age, sex, high weight and family history. It is clear the importance of modifying changeable factors for reduction of SAH and improvement of quality of life in this population. (Chart 2).

The third category describes the adverse events of ART that contribute to SAH. The protease inhibitors were highlighted when dealing with side effects of ART including medicamental interaction with some antihypertensive medicines. We see there is no definition whether ART influences the SAH development, which opens space for new studies on the subject (Chart 3).

Chart 1 - Prevalence of Systemic Arterial Hypertension in people living with HIV/AIDS, 2016

\begin{tabular}{|c|c|c|c|c|}
\hline Title & $\begin{array}{l}\text { Year/ } \\
\text { Country }\end{array}$ & $\begin{array}{c}\text { Study outline/ } \\
\text { number of patients }\end{array}$ & Intervention & Outcome \\
\hline $\begin{array}{l}\text { Prevalence and patient awareness of } \\
\text { medical comorbidities in an urban AIDS } \\
\text { clinic }^{(18)}\end{array}$ & $\begin{array}{l}\text { United } \\
\text { States } \\
2010\end{array}$ & $\begin{array}{l}\text { Cross-sectional } \\
\mathrm{n}=200\end{array}$ & Interview with use of a form & $\begin{array}{l}\text { Prevalence of SAH on } \\
27.5 \% \text { black people. }\end{array}$ \\
\hline $\begin{array}{l}\text { Chronic illness burden and quality of } \\
\text { life in an aging HIV population }{ }^{(19)}\end{array}$ & $\begin{array}{l}\text { United } \\
\text { States } \\
2013\end{array}$ & $\begin{array}{l}\text { Cross-sectional } \\
\quad n=452\end{array}$ & Interview on the phone & $\begin{array}{l}\text { Prevalence of SAH on } \\
46 \% \text { people aged } 50 \text { or } \\
\text { older. }\end{array}$ \\
\hline $\begin{array}{l}\text { Risk factors related to hypertension } \\
\text { among patients in a cohort living with } \\
\text { HIV/AIDS }^{(10)}\end{array}$ & $\begin{array}{l}\text { Brazil } \\
2010\end{array}$ & $\begin{array}{l}\text { Case control } \\
\mathrm{n}=958\end{array}$ & $\begin{array}{l}\text { Observing groups } \\
\text { Case: patients with AP (Arterial } \\
\text { Pressure) }>140 / 90 \mathrm{mmHg} \text {, at } \\
\text { least on two occasions, or previous } \\
\text { diagnosis of hypertension. Control: } \\
\text { patients with normal AP }\end{array}$ & $\begin{array}{l}\text { Prevalence of } \mathrm{SAH} \text { in } \\
25.6 \% \text { people followed } \\
\text { up in the clinic. }\end{array}$ \\
\hline $\begin{array}{l}\text { Risco cardiovascular: marcadores } \\
\text { antropométricos, clínicos e dietéticos em } \\
\text { indivíduos infectados pelo vírus HIV }{ }^{(11)}\end{array}$ & $\begin{array}{l}\text { Brazil } \\
2011\end{array}$ & $\begin{array}{l}\text { Cross-sectional } \\
\qquad n=100\end{array}$ & $\begin{array}{l}\text { Interview and physical } \\
\text { examination }\end{array}$ & $\begin{array}{l}\text { Prevalence of SAH in } \\
35 \% \text { people followed } \\
\text { up in the clinic. }\end{array}$ \\
\hline
\end{tabular}


Chart 1 (concluded)

\begin{tabular}{|c|c|c|c|c|}
\hline Title & $\begin{array}{l}\text { Year/ } \\
\text { Country }\end{array}$ & $\begin{array}{l}\text { Study outline/ } \\
\text { number of patients }\end{array}$ & Intervention & Outcome \\
\hline $\begin{array}{l}\text { What should we know about metabolic } \\
\text { syndrome and lipodystrophy in AIDS }\end{array}$ & $\begin{array}{l}\text { Brazil } \\
2011\end{array}$ & $\begin{array}{l}\text { Cross-sectional } \\
\mathrm{n}=819\end{array}$ & $\begin{array}{l}\text { Interview and physical } \\
\text { examination }\end{array}$ & $\begin{array}{l}\text { Prevalence of SAH in } \\
16.7 \% \text { people followed } \\
\text { up in the clinic. }\end{array}$ \\
\hline $\begin{array}{l}\text { Aging with HIV: an overview of an } \\
\text { urban cohort in Rio de Janeiro (Brazil) } \\
\text { across decades of life } \text { (14) }^{\text {a }}\end{array}$ & $\begin{array}{l}\text { Brazil } \\
2013\end{array}$ & $\begin{array}{l}\text { Cross-sectional } \\
\mathrm{n}=2.307\end{array}$ & Medical Record & $\begin{array}{l}\text { Prevalence of SAH in } \\
11.9 \% \text { people followed } \\
\text { up in the clinic. }\end{array}$ \\
\hline $\begin{array}{l}\text { Risk of coronary artery disease in } \\
\text { individuals infected with human } \\
\text { immunodeficiency virus }{ }^{(15)}\end{array}$ & $\begin{array}{l}\text { Brazil } \\
2011\end{array}$ & $\begin{array}{c}\text { Cross-sectional } \\
n=40\end{array}$ & & $\begin{array}{l}\text { Prevalence of SAH in } \\
55 \% \text { people followed } \\
\text { up in the clinic. }\end{array}$ \\
\hline $\begin{array}{l}\text { Correlates of hypertension in patients } \\
\text { with AIDS in the era of highly-active } \\
\text { antiretroviral therapy }{ }^{(20)}\end{array}$ & $\begin{array}{l}\text { United } \\
\text { States } \\
2013\end{array}$ & $\begin{array}{l}\text { Prospective cohort } \\
\quad \mathrm{n}=2390\end{array}$ & $\begin{array}{l}\text { Interview, medical record and } \\
\text { examinations }\end{array}$ & $\begin{array}{l}\text { Prevalence of SAH on } \\
22 \% \text { and incidence in } \\
64.1 / 1000 .\end{array}$ \\
\hline $\begin{array}{l}\text { Impact of highly active antiretroviral } \\
\text { therapy on blood pressure in HIV- } \\
\text { infected patients. A prospective study in } \\
\text { a cohort of naive patients }{ }^{(23)}\end{array}$ & $\begin{array}{l}\text { Spain } \\
2006\end{array}$ & $\begin{array}{l}\text { Prospective cohort } \\
\qquad \mathrm{n}=95\end{array}$ & $\begin{array}{l}\text { Interview and physical } \\
\text { examination }\end{array}$ & $\begin{array}{l}\text { Before ARTt, } 7 \% \text { patients } \\
\text { had SAH; } \\
\text { After } 48 \text { weeks of ART, } \\
26 \% \text { were with high AP } \neq\end{array}$ \\
\hline $\begin{array}{l}\text { Lipid profile, cardiovascular risk } \\
\text { factors and metabolic syndrome in a } \\
\text { group of AIDS patients }{ }^{(13)}\end{array}$ & $\begin{array}{l}\text { Brazil } \\
2008\end{array}$ & $\begin{array}{l}\text { Cross-sectional } \\
\mathrm{n}=252\end{array}$ & $\begin{array}{l}\text { Interview and physical } \\
\text { examination }\end{array}$ & $\begin{array}{l}\text { In use of ART: } 19.9 \% \\
\text { patients had SAH; } \\
\text { No use of ART: } 13.3 \% \\
\text { had SAH. }\end{array}$ \\
\hline $\begin{array}{l}\text { Prevalence of hypertension in HIV/AIDS } \\
\text { patients on highly active antiretroviral } \\
\text { therapy (haart) compared with haart } \\
\text { naïve patients at the limbe regional } \\
\text { hospital, Cameroon }{ }^{(25)}\end{array}$ & $\begin{array}{l}\text { Cameroon } \\
2016\end{array}$ & $\begin{array}{l}\text { Cross-sectional } \\
\mathrm{n}=200\end{array}$ & $\begin{array}{l}\text { Interview and physical } \\
\text { examination }\end{array}$ & $\begin{array}{l}\text { In use of ART: } 38 \% \\
\text { patients had SAH; } \\
\text { No use of ART: } 19 \% \\
\text { had SAH. }\end{array}$ \\
\hline
\end{tabular}

Nota: *HAS: Hipertensão arterial sistêmica; †TARV: Terapia antirretroviral; ¥PA: Pressão arterial.

Chart 2 - Risk factors for Systemic Arterial Hypertension in people living with HIV/AIDS, 2016

\begin{tabular}{|c|c|c|c|c|}
\hline Title & $\begin{array}{c}\text { Year/ } \\
\text { Country }\end{array}$ & $\begin{array}{l}\text { Study outline/ } \\
\text { number of } \\
\text { patients }\end{array}$ & Intervention & Outcome \\
\hline $\begin{array}{l}\text { Risk factors related to } \\
\text { hypertension among patients } \\
\text { in a cohort living with HIV/ } \\
\text { AIDS }^{(10)}\end{array}$ & $\begin{array}{l}\text { Brazil } \\
2010\end{array}$ & $\begin{array}{l}\text { Case control } \\
\mathrm{n}=958\end{array}$ & $\begin{array}{l}\text { Observing groups } \\
\text { Case: patients } \\
\text { with AP > 140/90 } \\
\text { mmHg, at least on } \\
\text { two occasions, or } \\
\text { previous diagnosis } \\
\text { of hypertension. } \\
\text { Control: patients } \\
\text { with normal AP }\end{array}$ & $\begin{array}{l}\text { - Advanced age } \\
\text { - Longest time of anti-HIV positive serology } \\
\text { - Use of ART: } \\
\text { - SAH+ family history } \\
\text { - Low CD4+ T lymphocytes } \\
\text { - Sedentariness: } \\
\text { - BMIf }>25 \mathrm{~kg} / \mathrm{m} \\
\text { - High Waist Circumference } \\
\text { - Triglycerides }>150 \mathrm{mg} / \mathrm{dL} \\
\text { - Blood Glucose }>100 \mathrm{mg} / \mathrm{dL} \\
\text { - Cholesterol }>200 \mathrm{mg} / \mathrm{dL}\end{array}$ \\
\hline $\begin{array}{l}\text { What should we know about } \\
\text { metabolic syndrome and } \\
\text { lipodystrophy in AIDS? } \text { (12) }^{(2)}\end{array}$ & $\begin{array}{l}\text { Brazil } \\
2011\end{array}$ & $\begin{array}{l}\text { Cross-sectional } \\
\mathrm{n}=819\end{array}$ & $\begin{array}{l}\text { Interview } \\
\text { and physical } \\
\text { examination }\end{array}$ & $\begin{array}{l}\text { - Advanced age } \\
\text { - Longest time of anti-HIV positive serology } \\
\text { - Use of ART: } \\
\text { - High CD4 + T lymphocytes } \\
\text { - BMI‡ > } 25 \mathrm{~kg} / \mathrm{m}\end{array}$ \\
\hline $\begin{array}{l}\text { Aging with HIV: an overview } \\
\text { of an urban cohort in Rio de } \\
\text { Janeiro (Brazil) across decades } \\
\text { of life }^{(14)}\end{array}$ & $\begin{array}{l}\text { Brazil } \\
2013\end{array}$ & $\begin{array}{c}\text { Cross-sectional } \\
\mathrm{n}=2307\end{array}$ & $\begin{array}{l}\text { Analysis on medical } \\
\text { records }\end{array}$ & - Advanced age \\
\hline $\begin{array}{l}\text { Hospitalizations for } \\
\text { cardiovascular disease in } \\
\text { african americans and whites } \\
\text { with } \\
\text { HIV/AIDS }\end{array}$ & $\begin{array}{l}\text { United } \\
\text { States } \\
2013\end{array}$ & $\begin{array}{c}\text { Retrospective } \\
\text { cohort } \\
n=288\end{array}$ & $\begin{array}{l}\text { Medical records } \\
\text { analysis }\end{array}$ & $\begin{array}{l}\text { - Advanced age } \\
\text { - Black } \\
\text { - Women } \\
\text { - Chronic Kidney Disease }\end{array}$ \\
\hline
\end{tabular}




\begin{tabular}{|c|c|c|c|c|}
\hline Title & $\begin{array}{l}\text { Year/ } \\
\text { Country }\end{array}$ & $\begin{array}{c}\text { Study outline/ } \\
\text { number of } \\
\text { patients }\end{array}$ & Intervention & Outcome \\
\hline $\begin{array}{l}\text { Chronic illness burden and } \\
\text { quality of life in an aging HIV } \\
\text { population }{ }^{(19)}\end{array}$ & $\begin{array}{l}\text { United } \\
\text { States } \\
2013\end{array}$ & $\begin{array}{l}\text { Cross-sectional } \\
\mathrm{n}=452\end{array}$ & $\begin{array}{l}\text { Interview on the } \\
\text { phone }\end{array}$ & $\begin{array}{l}\text { - Advanced age } \\
\text { - Stress and depression } \\
\text { - Low social and mental activity }\end{array}$ \\
\hline $\begin{array}{l}\text { Correlates of hypertension in } \\
\text { patients with AIDS in the era } \\
\text { of highly-active antiretroviral } \\
\text { therapy } 20)\end{array}$ & $\begin{array}{l}\text { United } \\
\text { States } \\
2013\end{array}$ & $\begin{array}{l}\text { Retrospective } \\
\text { cohort } \\
\mathrm{n}=2390\end{array}$ & $\begin{array}{l}\text { Interview, medical } \\
\text { records analysis and } \\
\text { examinations }\end{array}$ & $\begin{array}{l}\text { - Advanced age } \\
\text { - Black } \\
\text { - Diabetes Mellitus } \\
\text { - Low educational level } \\
\text { - High weight } \\
\text { - Triglycerides > } 150 \mathrm{mg} / \mathrm{dL}\end{array}$ \\
\hline $\begin{array}{l}\text { Hipertensión arterial, } \\
\text { infección por el virus de la } \\
\text { inmunodeficiencia humana y } \\
\text { tratamiento antirretrovírico de } \\
\text { gran actividad }^{(21)}\end{array}$ & $\begin{array}{l}\text { Spain } \\
2010\end{array}$ & Integrative review & $\begin{array}{l}\text { Search on MEDLINE } \\
\text { database }\end{array}$ & $\begin{array}{l}\text { - Advanced age } \\
\text { - Men } \\
\text { - Low pre-treatment systolic pressure with ART } \\
\text { - Low CD4+ T lymphocytes } \\
\text { - Chronic kidney disease } \\
\text { - Lipodystrophy } \\
\text { - High Waist Circumference } \\
\text { - Triglycerides }>150 \mathrm{mg} / \mathrm{dL} \\
\text { - Cholesterol }>200 \mathrm{mg} / \mathrm{dL}\end{array}$ \\
\hline $\begin{array}{l}\text { Impact of highly active } \\
\text { antiretroviral therapy on blood } \\
\text { pressure in HIV-infected patients. } \\
\text { A prospective study in a cohort } \\
\text { of naive patients }{ }^{(23)}\end{array}$ & $\begin{array}{l}\text { Spain } \\
2006\end{array}$ & $\begin{array}{l}\text { Retrospective } \\
\text { cohort } \\
\mathrm{n}=95\end{array}$ & $\begin{array}{l}\text { Interview } \\
\text { and physical } \\
\text { examination }\end{array}$ & $\begin{array}{l}\text { - Advanced age } \\
\text { - Low CD4 + T lymphocytes } \\
\text { - BMIf > } 25 \mathrm{~kg} / \mathrm{m} \\
\text { - Triglycerides > } 150 \mathrm{mg} / \mathrm{dL} \\
\text { - Cholesterol > } 200 \mathrm{mg} / \mathrm{dL}\end{array}$ \\
\hline $\begin{array}{l}\text { Prevalence of hypertension in } \\
\text { HIV/AIDS Patients on highly } \\
\text { active antiretroviral therapy } \\
\text { (HAART) compared with HAART } \\
\text { naive patients at the limbe } \\
\text { regional hospital, Cameroon }\end{array}$ & $\begin{array}{l}\text { Cameroon } \\
2016\end{array}$ & $\begin{array}{l}\text { Cross-sectional } \\
\mathrm{n}=200\end{array}$ & $\begin{array}{l}\text { Interview } \\
\text { and physical } \\
\text { examination }\end{array}$ & $\begin{array}{l}\text { - Advanced age } \\
\text { - Men } \\
\text { - Use of ART: }\end{array}$ \\
\hline $\begin{array}{l}\text { Prevalence and patient awareness } \\
\text { of medical comorbidities in an } \\
\text { urban AIDS clinic }{ }^{(18)}\end{array}$ & $\begin{array}{l}\text { United } \\
\text { States } \\
2010\end{array}$ & $\begin{array}{l}\text { Cross-sectional } \\
\mathrm{n}=200\end{array}$ & $\begin{array}{l}\text { Filling out cards, } \\
\text { interview and } \\
\text { medical records }\end{array}$ & $\begin{array}{l}\text { - Women } \\
\text { - Longest time of anti-HIV positive serology } \\
\text { - Use of ART: }\end{array}$ \\
\hline $\begin{array}{l}\text { Cardiovascular profile and events } \\
\text { of US adults } 20-49 \text { years with } \\
\text { HIV: results from the NHANES } \\
1999-2008^{(17)}\end{array}$ & $\begin{array}{l}\text { United } \\
\text { States } \\
2013\end{array}$ & $\begin{array}{l}\text { Cross-sectional } \\
\mathrm{n}=12.339\end{array}$ & $\begin{array}{l}\text { Data analysis of the } \\
\text { National Center for } \\
\text { Health Statistics. }\end{array}$ & - Longest time of anti-HIV positive serology \\
\hline $\begin{array}{l}\text { Lipid profile, cardiovascular risk } \\
\text { factors and metabolic syndrome } \\
\text { in a group of AIDS patients }{ }^{(13)}\end{array}$ & $\begin{array}{l}\text { Brazil } \\
2008\end{array}$ & $\begin{array}{c}\text { Cross-sectional } \\
\mathrm{n}=252\end{array}$ & $\begin{array}{l}\text { Interview } \\
\text { and physical } \\
\text { examination }\end{array}$ & $\begin{array}{l}\text { - Diabetes Mellitus } \\
\text { - Arteriosclerosis } \\
\text { - Smoking }\end{array}$ \\
\hline $\begin{array}{l}\text { Risco cardiovascular: marcadores } \\
\text { antropométricos, clínicos } \\
\text { e dietéticos em indivíduos } \\
\text { infectados pelo vírus HIV }{ }^{(11)}\end{array}$ & $\begin{array}{l}\text { Brazil } \\
2011\end{array}$ & $\begin{array}{l}\text { Cross-sectional } \\
\mathrm{n}=100\end{array}$ & $\begin{array}{l}\text { Interview } \\
\text { and physical } \\
\text { examination }\end{array}$ & $\begin{array}{l}\text { - Smoking } \\
\text { - Blood Glucose > } 100 \mathrm{mg} / \mathrm{dL} \\
\text { - Cholesterol > } 200 \mathrm{mg} / \mathrm{dL} \\
\text { - Low values of high density lipoproteins }\end{array}$ \\
\hline
\end{tabular}

Note: *ART: Antiretroviral Therapy; $+S A H$ : Systemic Arterial Hypertension; $¥ B M I: B o d y$ Mass Index

Chart 3 - Antiretroviral therapy adverse events that contribute to systemic arterial hypertension, 2016

\begin{tabular}{|l|c|c|l|l|}
\hline \multicolumn{1}{|c|}{ Title } & $\begin{array}{c}\text { Year/ } \\
\text { Country }\end{array}$ & $\begin{array}{c}\text { Study outline/ } \\
\text { number of patients }\end{array}$ & Intervention & \multicolumn{1}{c|}{ Outcome } \\
\hline $\begin{array}{l}\text { Hipertensión arterial } \\
\text { en pacientes infectados } \\
\text { por el virus de la } \\
\text { inmunodeficiencia } \\
\text { humana(22) }\end{array}$ & $\begin{array}{c}\text { Spain } \\
2013\end{array}$ & Integrative review & Search in database & $\begin{array}{l}\text { - Protease inhibitors (ritonavir, indinavir, } \\
\text { saquinavir, lopinavir, nelfinavir and } \\
\text { amprenavir): Increase of AP* and } \\
\text { potentialization or decrease of the effect of } \\
\text { calcium channel blockers. } \\
\text { - Nevirapine: Interaction with calcium } \\
\text { channel blockers } \\
\text { - Delavirdine: Increases plasmatic levels of } \\
\text { antihypertensive medicines }\end{array}$ \\
\hline
\end{tabular}




\begin{tabular}{|l|c|c|l|l|}
\hline \multicolumn{1}{|c|}{ Title } & $\begin{array}{c}\text { Year/ } \\
\text { Country }\end{array}$ & $\begin{array}{c}\text { Study outline/ } \\
\text { number of patients }\end{array}$ & Intervention & Outcome \\
\hline $\begin{array}{l}\text { Cardiovascular } \\
\text { manifestations of HIV } \\
\text { infection(24) }\end{array}$ & $\begin{array}{c}\text { Italy } \\
2001\end{array}$ & Integrative review & Search in database & $\begin{array}{l}\text { - Protease inhibitors (ritonavir, indinavir, } \\
\text { saquinavir, lopinavir, nelfinavir and } \\
\text { amprenavir): } \\
\text { Coronary artery disease, lipodystrophy, } \\
\text { insulin resistance, high cholesterol, high } \\
\text { triglycerides and infarction. }\end{array}$ \\
\hline $\begin{array}{l}\text { Una década de terapia anti- } \\
\text { retroviral: perfil de pacientes } \\
\begin{array}{l}\text { con 10 años de triterapia de } \\
\text { alta efectividad }\end{array}\end{array}$ & $\begin{array}{c}\text { Chile } \\
2012\end{array}$ & Retrospective cohort & $\begin{array}{l}\text { Medical records } \\
\text { analysis }\end{array}$ & $\begin{array}{l}\text { - Lipodystrophy } \\
\text { - High triglycerides }\end{array}$ \\
\hline
\end{tabular}

Note: *AP: Arterial Pressure

\section{DISCUSSION}

The incidence and prevalence of SAH in PLWHA is growing and there is no consensus whether HIV and ART are associated with this growth, or individual factors influence more dramatically the appearance of this comorbidity. The high prevalence rates of medical comorbidities unrelated to HIV found in this population are alarming, and we can claim that people with HIV/AIDS are living longer and dying due to health problems that are not connected to HIV/AIDS ${ }^{(18,27)}$.

This study found a higher prevalence of SAH in black PLWHA. Physiologically speaking, one of the reasons that may explain this finding is that black people tend to have lower rates of CD4 + T lymphocytes, which is a risk factor for development of $\mathrm{SAH}^{(21,25)}$. In addition, a study showed that these individuals have less access to healthcare services, which can contribute to this disparity ${ }^{(16)}$. Regarding sex, there is no consensus about what would be a risk factor, although males are more prevalent in studies as a risk factor for $\mathrm{SAH}^{(10,21,25)}$.

Advanced age, especially over 50, becomes a key factor for the development of SAH in this population.Other studies show that SAH is the most important comorbidity among the elderly ${ }^{(28-29)}$. Therefore, elders with HIV/AIDS are more vulnerable, so we noticed they have more chronic conditions than elders who do not live with HIV/AIDS. This leads to a need that is achieved with patient-centered care, overcoming barriers of medical fragmentation and understanding patients as a whole, since PLWHA are also susceptible to other chronic comorbidities, and SAH is one of the main ones ${ }^{(19)}$.

Our study and the literature indicate that individuals with low educational background have a higher number of chronic diseases, thus, we can be observe the great impact that the educational level can generate to conditions and quality of life of people, which reflects on their health ${ }^{(30)}$.

High weight stands out as one of the main risk factors for development of SAH. Before starting the treatment, the PLWHA usually suffers a severe weight loss, which after finding out, leads to carelessness with diet and healthy living habits, for fear of appearing to be sick. As a result, many patients get fat, not worrying about their health and the consequences, which leads to development of chronic diseases as SAH. On the other hand, the medicines can cause weight gain, usually in a specific area, which causes lipodystrophy, another strong risk factor for $\mathrm{SAH}^{(10)}$.

In addition, the excessive body mass may be responsible for $20 \%$ to $30 \%$ of cases of $\mathrm{SAH}$, especially when fat deposition concentrates on the abdominal area. Thus, it is suggested that such factors must be worked through practice of physical exercise and nutritional guidance, which contribute to prevention and a better control of $\mathrm{SAH}^{(31)}$. It is important to note that central obesity is involved in the metabolic syndrome genesis, and is responsible for emergence of resistance to insulin, SAH and dyslipidemia, therefore increasing cardiovascular risk of individuals ${ }^{(32)}$.

The infection treatment can lead to appearance of some associated conditions, such as high levels of triglycerides, total cholesterol and LDL cholesterol increase, in addition to decrease in HDL cholesterol ${ }^{(33)}$. The association between dyslipidemia and SAH may also be a result of hypercholesterolemia contribution to raise arterial pressure through activation of the renin-angiotensin-aldosterone system, reduction of nitric oxide availability, endothelial dysfunction, among other factors involved ${ }^{(32)}$. However, we observed that diet of PLWHA, in general, is rich in fats and cholesterol and poor in fiber, combined with a low ingestion of vegetables, fruits and dairy products, which leads to dyslipidemia ${ }^{(11)}$.

Diabetes is another factor directly related to SAH. Diabetes and $\mathrm{SAH}$ share common pathways, such as sympathetic nervous system, renin-angiotensin-aldosterone system, oxidative stress, adipokine and resistance to insulin. These pathways interact, influence each other and can even cause a vicious cycle. SAH and diabetes are the two final results of the metabolic syndrome and as a consequence, may develop one after another in the same individual ${ }^{(34)}$. The increased survival rate resulting from ART has been achieved at the expense of high incidence of unforeseen adverse metabolic effects, including insulin resistance, diabetes, dyslipidemia and lipodystrophy ${ }^{(35)}$.

Besides, we verified that the smoking habit is highly prevalent among the PLWHA and is strongly associated to increase of prevalence of chronic diseases related to tobacco use disorder, especially cardiovascular diseases. Patients who are not following rigorously the therapy or did not start ART are more likely to smoke, since a study showed that these individuals have more difficulty to have healthy lifestyle habits. However, it is necessary to pay attention to other factors involved, such as sociodemographic 
and clinical ones, which affect medication adherence and may also represent barriers to tobacco use cessation ${ }^{(36)}$.

PLWHA are susceptible to higher rates of depression over the years than the general population, which may affect negatively tobacco use cessation ${ }^{(19)}$, as well as demonstrated in the results of this integrative review. In addition, a meta-analysis study concluded that the influence of depression on hypertension is timedependent, and these are the main reasons: depression symptoms lead to unhealthy lifestyles; depression may be associated with deregulation in the hypothalamic-pituitary-adrenal axis; depression is associated to dysfunction of the autonomic nervous system, which contributes to arterial pressure elevation ${ }^{(37)}$.

The ART can be associated with an adverse profile of cardiovascular risk factors ${ }^{(38)}$. Such adverse events are more likely to happen in the first six months of ART, thus, the monitoring of patients by healthcare professionals is essential at the beginning of therapy ${ }^{(39)}$. There is the possibility that PLWHA might be more susceptible to $\mathrm{SAH}$, probably not only related to the virus, but also to ART, as well as to treatments containing protease inhibitors, which are related to the development of $\mathrm{SAH}$ and lipodystrophy. In addition, other medications, such as nevirapine and delavirdine may have medicamental interaction with antihypertensive medicines ${ }^{(29)}$. Protease inhibitors cause metabolic effects, including insulin resistance, which can cause diabetes ${ }^{(35)}$.

Therefore, considering all the aforementioned aspects, PLWHA must no longer be educated only about their health condition regarding HIV; it is also necessary care and guidance about other health conditions, as $\mathrm{SAH}$, in order to offer a full and effective assistance to those patients ${ }^{(18)}$.

Study limitations and contributions to the healthcare field

One limitation of this study is that there was no controlled randomized clinical trials to test many factors and observe the relationship between HIV/AIDS and SAH, since most studies found were merely descriptive. With this in mind, we believe new and more deep research about the topic is necessary. The contribution of this study is the collection and organization of existing data on the HIV influence on the development of $\mathrm{SAH}$, making visible the points that need to be examined more carefully, and to raise the importance of the topic for PLWHA.

\section{CONCLUSION}

This study reviewed the scientific literature on the relationship between HIV/AIDS and SAH. We verified that the studies covered the following topics: prevalence of SAH in PLWHA; risk factors for SAH in PLWHA; and adverse events of ART that contribute to $\mathrm{SAH}$. In addition, guidelines and interventions for the prevention of SAH must be performed in all individuals; however, in PLWHA, they must be carried out in a special way and focusing on the characteristic risk factors of this population, since it is not consistently known whether ART or HIV increase SAH predisposition in PLWHA, or it occurs only due to increase of survival rate provided by ART.

Moreover, it is necessary for healthcare professionals to have an integrative look over PLWHA, beyond the HIV infection, observing that these individuals are vulnerable to other chronic conditions as well. As influencing factors for the development of SAH, we noticed predisposing and individual risk factors, such as advanced age, black race, low educational background and SAH family history, as well as risk factors probably resulting from HIV and ART, such as lipodystrophy, insulin resistance, high cholesterol and triglycerides. With this is mind, these patients must be guided about the modification of the changeable risk factors and search for a healthier lifestyle.

\section{REFERENCES}

1. Cruz RADO. Aprendizagem significativa e teatro como estratégias de prevenção do HIV em adolescentes: relatando a experiência. Rev Tend Enferm Prof [Internet]. 2013[cited 2016 May 7];5(1):866-9. Available from: http://www.repositorio.ufc.br/ri/bitstream/ riufc/7821/1/2013_art_cmrmedeiros1.pdf

2. Felix G, Ceolim MFO. The profile of women with HIV/AIDS and their adherence to the antiretroviral therapy. Rev Esc Enferm USP [Internet]. 2012[cited 2016 May 4];46(4):884-91. Available from: http://www.scielo.br/pdf/reeusp/v46n4/en_15.pdf

3. Pereira PS, Costa MCO, Amaral MTR, Costa HS, Silva CAL, Sampaio VS. [Factors associated with HIV/AIDS infection among adolescents and young adults enrolled in a Counseling and Testing Center in the State of Bahia, Brazil]. Cienc Saude Colet [Internet]. 2014 [cited 2016 Jun 12];19(3):747-58. Available from: http://www.scielo.br/pdf/csc/v19n3/1413-8123-csc-19-03-00747.pdf Portuguese

4. Lima TC, Freitas MIC. [Health Behavior in a population with HIV/Aids]. Rev Bras Enferm [Internet]. 2012 [cited 2016 Jun 12];65(1):110-5. Available from: http://www.scielo.br/pdf/reben/v65n1/16.pdf Portuguese

5. Pereira IMO. Proposta de intervenção interdisciplinar para a adesão dos pacientes ao tratamento da hipertensão arterial sistêmica. Liph Science [Internet]. 2015[cited 2016 Jun 12];2(2):21-40. Available from: http://crfmg.org.br/comunicacao/proposta\%20 de\%20intervencao.pdf

6. Arruda LM, Oliveira JM, Cotta RMM, Ribeiro SMR. Perfil sociossanitário de portadores de hipertensão arterial cadastrados na estratégia de saúde da família, Divinésia, Minas Gerais. Rev APS [Internet]. 2015[cited 2016 Jun 3];18(1):78-84. Available from: https://aps.ufjf.emnuvens.com.br/aps/article/view/2220/862

7. Bezerra VM, Andrade ACS, César CC, Caiffa WT. Unawareness of hypertension and its determinants among 'quilombolas' (inhabitants of 'quilombos': hinterland settlements founded by people of African origin) living in Southwest Bahia, Brazil. Cienc 
Saude Colet [Internet]. 2015[cited 2016 Jun 3];20(3):797-807. Available from: http://www.scielo.br/pdf/csc/v20n3/1413-8123csc-20-03-00797.pdf

8. Souza MT, Silva MD, Carvalho R. Revisão integrativa: o que é e como fazer. Rev Einstein[Internet]. 2010 [cited 2016 Jun 15];8(1):102-6. Available from: http://www.scielo.br/pdf/eins/v8n1/pt_1679-4508-eins-8-1-0102.pdf

9. Melnyk BM, Fineout-Overholt E. Making the case for evidence-based practice. In: Melnyk BM, Fineout-Overholt E, (eds). Evidencebased practice in nursing \& healthcare: a guide to best practice. Philadelphia: Lippincott Williams \& Wilkins; 2011.

10. Arruda Junior ER, Lacerda HR, Moura LCRV, Albuquerque MFPM, Miranda Filho DB, Diniz GT, et al. Risk factors related to hypertension among patients in a cohort living with HIV/AIDS. Braz J Infect Dis [Internet]. 2010[cited 2016 May 16];14(3):281-7. Available from: http://www.scielo.br/pdf/bjid/v14n3/v14n3a14.pdf

11. Leite LHM, Sampaio ABMM. Risco cardiovascular: marcadores antropométricos, clínicos e dietéticos em indivíduos infectados pelo vírus HIV. Rev Nutr [Internet]. 2011[cited 2016 May 13];24(1):79-88. Available from: http://www.scielo.br/pdf/rn/v24n1/ v24n1a08.pdf

12. Signorini DJHP, Monteiro MCM, Andrade MFC, Signorini DH, Eyer-Silva WA. What should we know about metabolic syndrome and lipodystrophy in AIDS? Rev Assoc Med Bras [Internet]. 2011[cited 2016 May 15];58(1):70-5. Available from: http://www. scielo.br/pdf/ramb/v58n1/v58n1a17.pdf

13. Silva EFR, Bassichetto KC, Lewi DS. Lipid Profile, Cardiovascular Risk Factors and Metabolic Syndrome in a Group of AIDS Patients. Arq Bras Cardiol [Internet]. 2008[cited 2016 Jun 15];93(2):113-8. Available from: http://www.scielo.br/pdf/abc/v93n2/ en_v93n2a08.pdf

14. Torres TS, Cardoso SW, Velasque LS, Marins LMS, Oliveira MS, Veloso VG, et al. Aging with HIV: an overview of an urban cohort in Rio de Janeiro (Brazil) across decades of life. Braz J Infect Dis [Internet]. 2013[cited 2016 May 15];17(3):324-31. Available from: http://www.sciencedirect.com/science/article/pii/S1413867013000640

15. Vilela FD, Lorenzo AR, Tura BR, Ferraiuoli GI, Hadlich M, Barros MVL, et al. Risk of coronary artery disease in individuals infected with human immunodeficiency virus. Braz J Infect Dis [Internet]. 2011[cited 2016 May 15];15(6):521-7. Available from: http://www.scielo.br/pdf/bjid/v15n6/v15n6a04.pdf

16. Oramasionwu CU, Morse GD, Lawson KA, Brown CM, Koeller JM, Frei CR. Hospitalizations for Cardiovascular Disease in African Americans and Whites with HIV/AIDS. Popul Health Manag [Internet]. 2013[cited 2016 May 23];16(3):201-7. Available from: http://www.ncbi.nlm.nih.gov/pmc/articles/PMC3840471/pdf/pop.2012.0043.pdf

17. Gutierrez J, Elkind MSV, Marshall RS. Cardiovascular profile and events of US adults 20-49 years with HIV: results from the nhanes 1999-2008. AIDS Care [Internet]. 2013[cited 2016 May 1];25(11):1385-91. Available from: http://www.tandfonline.com/doi/abs/ 10.1080/09540121.2013.769493?journalCode = caic20

18. Weiss JJ, Osorio G, Ryan E, Marcus SM, Fishbein DA. Prevalence and Patient Awareness of Medical Comorbidities in an Urban Aids Clinic. AIDS Patient Care STDS [Internet]. 2010[cited 2016 May 14];24(1):39-48. Available from: http://www.ncbi.nlm.nih. gov/pmc/articles/PMC2859780/pdf/apc.2009.0152.pdf

19. Balderson BH, Grothaus L, Harrison RG, Mccoy K, Mahoney C, Catz S. Chronic illness burden and quality of life in an aging HIV population. AIDS Care [Internet]. 2013[cited 2016 May 16];25(4):451-8. Available from: http://www.ncbi.nlm.nih.gov/pmc/ articles/PMC3535557/pdf/caic25_451.pdf

20. Krauskopf K, Natta MLV, Danis RP, Gangaputra S, Ackatz L, Addessi A, et al. Correlates of hypertension in patients with AIDS in the era of highly-active antiretroviral therapy. J Int Assoc Provid AIDS Care [Internet]. 2013[cited 2016 May 17];12(5):325-33. Available from: http://www.ncbi.nlm.nih.gov/pmc/articles/PMC4100586/pdf/nihms598762.pdf

21. Serna JIB, Zamora FX, Montes ML, García-Puig J, Arribas JR. Hipertensión arterial, infección por el virus de la inmunodeficiencia humana y tratamiento antirretrovírico de gran actividad. Enferm Infecc Microbiol Clin [Internet]. 2010[cited 2016 May 15];28(1):32-7. Available from: http://www.elsevier.es/es-revista-enfermedades-infecciosas-microbiologia-clinica-28-pdf-S0213005X09001062-S300

22. Galvañ VG, Puerto MJG, Mas JR. Hipertensión arterial en pacientes infectados por el virus de la inmunodeficiencia humana. Hipertensión [Internet]. 2003[cited 2016 May 15];20(2):63-73. Available from: http://www.elsevier.es/ es-revista-hipertension-riesgo-vascular-67-pdf-S1889183703713518-S300

23. Palacios R, Santos J, García A, Castells E, González M, Ruiz J, et al. Impact of highly active antiretroviral therapy on blood pressure in HIV-infected patients: a prospective study in a cohort of naive patients. HIV Med [Internet]. 2006 [cited 2016 May 20];7(1):105. Available from: http://onlinelibrary.wiley.com/doi/10.1111/j.1468-1293.2005.00333.x/epdf

24. Barbaro G. Cardiovascular manifestations of HIV infection. J R Soc Med [Internet]. 2001[cited 2016 May 4];94(8):384-90. Available from: http://www.ncbi.nlm.nih.gov/pmc/articles/PMC1281631/pdf/0940384.pdf

25. Dimala CA, Atashili J, Mbuagbaw JC, Wilfred A, Monekosso GL. Prevalence of hypertension in HIV/AIDS patients on highly active antiretroviral therapy (HAART) compared with HAART Naïve Patients at the Limbe Regional Hospital, Cameroon. PLoS One [Internet]. 2016[cited 2016 May 16];11(2):1-11. Available from: http://journals.plos.org/plosone/article/asset?id =10.1371\%2Fjournal. pone.0148100.PDF

26. Wilson G, Wolff M. Una década de terapia anti-retroviral: Perfil de pacientes con 10 años de triterapia de alta efectividad. Rev Chilena Infectol [Internet]. 2012[cited 2016 May 14];29(3):337-43. Available from: http://www.scielo.cl/pdf/rci/v29n3/art15.pdf 
27. Nüesch R, Wang Q, Elzi L, Bernasconl E, Weber R, Cavassini M, et al. Risk of Cardiovascular Events and Blood Pressure Control in Hypertensive HIV-Infected Patients: Swiss HIV Cohort Study (SHCS). J Acquir Immune Defic Syndr [Internet]. 2013 [cited 2016 Jun 14];62(4):396-404. Available from: http://www.infekt.ch/content/uploads/2013/11/Nuesch_2013_Risk_of_Cardiovascular.pdf

28. Shah SS, Mcgowan PJ, Smith C, Blum S, Klein RS. Comorbid conditions, treatment, and health maintenance in older person with human imunodeficiency virus infection in New York City. HIV/AIDS CID [Internet]. 2002[cited 2016 Jun 15];35(1):1238-43. Available from: http://cid.oxfordjournals.org/content/35/10/1238.full.pdf + html

29. Adeyemi OM, Badri SM, Max B, Chinomona N, Barker, D. HIV Infection in Older Patients. Clin Infect Dis [Internet]. 2003[cited 2016 Jun 3];36(1):1347-58. Available from: http://cid.oxfordjournals.org/content/36/10/1347.full.pdf

30. Girotto E, Andrade SM, Cabrera MAS, Matsuo T. Adesão ao tratamento farmacológico e não farmacológico e fatores associados na atenção primária da hipertensão arterial. Cienc Saude Colet [Internet]. 2013[cited 2016 Jun 12];18(6):1763-72. Available from: www.scielo.br/pdf/csc/v18n6/27.pdf

31. Salomão CB, Santos LC, Ferreira AD, Lopes ACS. Fatores associados à hipertensão arterial em usuários de serviço de promoção à saúde. Rev Min Enferm [Internet]. 2013[cited 2016 Jun 12];17(1):32-8. Available from: http://www.reme.org.br/artigo/detalhes/577

32. Oliveira RAR, Mota Júnior RJ, Tavares DDF, Moreira OC, Marins JCB. Fatores associados à pressão arterial elevada em professores da educação básica. Rev Educ Física[Internet]. 2015[cited 2016 May 20];26(1):119-29. Available from: http://www.scielo.br/pdf/ refuem/v26n1/1983-3083-refuem-26-01-00119.pdf

33. Brasil. Ministério da Saúde. Secretaria de Vigilância em Saúde. Departamento de DST, Aids e Hepatites Virais. Boletim Epidemiológico - Aids e DST[Internet]. Brasília: Ministério da Saúde; 2015[cited 2016 Mar 30]. Available from: http://www.aids. gov.br/sites/default/files/anexos/publicacao/2015/58534/boletim_aids_11_2015_web_pdf_19105.pdf

34. Cheung BMY, Li C. Diabetes and Hypertension: is there a Common Metabolic Pathway? Curr Atheroscler Rep [Internet]. 2012[cited 2016 Jun 4];14(2):160-6. Available from: http://www.ncbi.nIm.nih.gov/pmc/articles/PMC3314178/pdf/11883_2012_Article_227.pdf

35. Dagogo-Jack S. HIV therapy and diabetes risk. Diabetes Care [Internet]. 2008[cited 2016 Jun 4];31(6):1267-8. Available from: http://care.diabetesjournals.org/content/diacare/31/6/1267.full.pdf

36. Regan S, Meigs JB, Grinspoon SK, Triant VA. Determinants of Smoking and Quitting in HIV-Infected Individuals. PLoS One [Internet]. 2016[cited 2016 Jun 12];11(4). Available from: http://journals.plos.org/plosone/article/asset?id=10.1371\%2Fjournal. pone.0153103.PDF

37. Meng L, Chen D, Yang Y, Zheng Y, Hui R. Depression increases the risk of hypertension incidence: a meta-analysis of prospective cohort studies. J Hypertens [Internet]. 2012[cited 2016 Jun 12];30(5):842-51. Available from: http://journals.Iww.com/ jhypertension/pages/articleviewer.aspx? year $=2012$ \&issue $=05000 \&$ article $=00002 \&$ type $=$ abstract

38. Eira M, Bensenor IM, Dorea EL, Cunha RS, Mill JG, Lotufo PA. Potent Antiretroviral Therapy for Human Immunodeficiency Virus Infection Increases Aortic Stiffness. Arq Bras Cardiol [Internet]. 2012[cited 2016 Jun 18];99(6):1100-7. Available from: http://www. scielo.br/pdf/abc/v99n6/en_aop10812.pdf

39. Eluwa GI, Badru T, Akpoigbe KJ. Adverse drug reactions to antiretroviral therapy (ARVs): incidence, type and risk factors in Nigeria. BMC Clin Pharmacol [Internet]. 2012[cited 2016 Jun 15];12(7). Available from: http://www.ncbi.nlm.nih.gov/pmc/ articles/PMC3317861/pdf/1472-6904-12-7.pdf 